\title{
The consequences of the COVID-19 pandemic on perceived stress in clinical practice: experience of doctors in Iraqi Kurdistan
}

\author{
DELDAR MORAD ABDULAH ${ }^{1}$, AYAD AHMAD MOHAMMED ${ }^{2}$
}

${ }^{1}$ Community Health Unit, College of Nursing, University of Duhok, Iraqi Kurdistan
${ }^{2}$ Department of Surgery, College of Medicine, University of Duhok, Iraqi Kurdistan

\begin{abstract}
Introduction. The healthcare workers are at high risk of developing stress-related problems during outbreaks. This study aimed to explore the perceived stress and its relation to the duration of dealing with COVID-19 patients in medical doctors.

Methods. The doctors who work in different medical settings in Iraqi Kurdistan during coronavirus outbreak were invited into this cross-sectional study. The doctors were invited from one pediatric, one emergency, one special corona, and one maternity and gynecology hospital. The "Perceived Stress Scale-10 (PSS)" measured the perceived degree of a doctor who experienced stress. The information was collected through a web-based technique to avoid the disease spread.

Results. Doctors' mean duration of dealing with suspected/confirmed cases of COVID-19 was 1.2 (Range: $0-16$ days). The mean stress score was 18.81 out of 40 . Most of the doctors had a moderate level of stress $(69.4 \%)$, followed by a low $(21.1 \%)$ and a high level of stress $(9.6 \%)$. The general physicians and medical lab specialties had higher stress scores; 21.56 and 19.88 , respectively. The high level of stress was among general physicians and community and family medicine doctors; $20.0 \%$ and $25.0 \%$, respectively. Whether or not doctors dealt with suspected/confirmed cases of COVID-19, did not have a significant difference over the perceived stress score; 19.02 vs. 18.87; $\mathrm{P}=0.786$ ). The mean score of stress was raised with increasing duration of dealing with suspected/confirmed cases of COVID-19; $\mathrm{r}=0.202 ; \mathrm{P}=0.004$ and decreased with increasing age $(\mathrm{r}=-0.141 ; \mathrm{P}=0.045)$, and clinical experience $(\mathrm{r}=-0.139, \mathrm{P}=0.048)$.

Conclusion. This study showed that medical doctors are at a moderate level of perceived stress during the COVID-19 outbreak in Iraqi Kurdistan.
\end{abstract}

Key words: stress, healthcare workers, clinical medicine, COVID-19, pandemics.

\section{What is new/what is important:}

The perceived stress during infection outbreaks may cause several mental health issues, including stress, anxiety, depressive symptoms, anger, insomnia, and fear. The mental health issues not only impact healthcare workers, attention, understanding, and decision making but also impact the overall wellbeing of medical doctors. It is essential to protect doctors against the mental health problems for the overall wellbeing.

\section{INTRODUCTION}

A novel coronavirus outbreak of pneumonia was originated from Wuhan, China, in December 2019 [1]. The outbreak had spread to almost all countries across the world [1]. The healthcare workers in Wuhan faced much pressure during their fight against the outbreak. The pressure they had to face was represented by a high risk of infection, insufficient protection from contamination, overwork, frustration, discrimination, isolation, dealing with patients with negative emotions, a lack of contact with their families, and exhaustion [2]. The severe state during any outbreak may cause several mental health issues, including stress, anxiety, depressive symptoms, anger, insomnia, and fear. The mental health issues not only impact healthcare workers attention, understanding, and decision making but also impact the overall wellbeing of medical doctors. It is essential to protect medical doctors against the mental health problems for the overall control of the epidemic and their long-term wellbeing [3]. It could be helpful to understand the mental health response following a public health emergency among medical workers [1].

Most of the general hospitals in Wuhan have established a shift system to allow frontline medical 
workers to rest and to take turns in high-pressured roles. Online platforms with medical advices were provided to share information on how to decrease the risk of transmission between the patients in medical settings, which aims to eventually reduce the pressure on medical workers [3].

There is a consensus that the COVID-19 pandemic not only affects physical health but also mental health and wellbeing $[4,5]$. The previous investigations have reported that healthcare workers who provide frontline care during viral epidemic outbreaks are at high risk for developing mental health issues [6]. The current pandemic is a relatively new kind of stressor or traumatic agent from a psychopathological point of view [3].

The psychological effects of the stress experienced by medical doctors during the COVID-19 outbreak may exert serious consequences on their overall wellbeing. Therefore, it is valuable to explore the level of the perceived stress in healthcare workers during the current outbreak.

The doctors who provide frontline healthcare during outbreaks are more likely to develop stress-related problems, both on the short and on the long term [7]. By 30 March 2020, the outbreak had spread to most of the countries and territories in the world; the number of confirmed reported cases was 963,000 and the number of deaths was 33,000 [8]. The early anecdotal evidence in Wuhan has shown that this situation has an impact on the mental status of physicians who provide the care in the frontline, including anxiety, depressive symptoms, anger, and fear [3].

This study aimed to measure the level of the perceived stress in medical doctors during coronavirus outbreak and to examine its relation to the duration of dealing with suspected/confirmed cases of COVID-19 in Iraqi Kurdistan.

\section{MATERIAL AND METHODS}

\section{STUDY DESIGN AND SAMPLING}

In the current cross-sectional study, the medical doctors who dealt with suspected or confirmed cases of COVID-19 in medical settings in Duhok city/Iraqi Kurdistan were invited regardless of the medical or sociodemographic perspectives. A list of doctors from all medical settings was taken from the local health authorities. The medical settings were one pediatric, one emergency, one special corona, and one maternity and gynecology hospital. An online Google Form was created based on a pre-designed questionnaire and was sent to the personal accounts of the doctors either through social media, email, or other online systems. The different medical specialties were invited into this study.

The medical doctors were invited from both gender and irrespective of medical and sociodemographic aspects. The online Google Form was sent to the doctors with an invitation message which described the aim of the study along with the consent form. The second notification was sent to all medical doctors to remind them to fill the submitted online questionnaire. The data collection was performed between 9th and 14th April 2020. Of the total 246 doctors who were invited, 209 of them (response rate: $85.31 \%$ ) returned the completed questionnaire. On, March 1st 2020, the Kurdistan Region Government (KRG) announced confirmed cases of COVID-19 in this region. The total required time to complete the questionnaire was 5 minutes only.

\section{DATA COLLECTION AND MEASURES}

The complete information of the study was collected through an online technique. The generally collected information was age, gender, experience in medicine since the graduation from the medical college, medical specialty, and the number of days that the doctors had dealt with the suspected or the confirmed cases of COVID-19 over the last month.

The medical specialties who were entered into the study were anesthesia and intensive care (including intensive care and emergency specialists), lab specialties, internal medicine, community and family medicine, surgery, general physicians, obstetrics and gynecology, pediatrics (including pediatrics and psychiatry), and radiology. The lab specialties were medical microbiology, biochemical, and hematology. The following specialties were categorized in internal medicine: cardiology, respiratory, general internal medicine, rheumatology, neurology, nephrology, and oncology. The following specialties were categorized in the surgery specialties; general surgery, urology, ENT, ophthalmology, and orthopedics.

The "Perceived Stress Scale-10 (PSS)" measured doctors' perceived degree of stress. The scale has ten items designed to find out how unpredictable, uncontrollable, and overloaded respondents find their lives. The items asked the doctors about their feelings and thoughts during the last month. It was rated on a 5-point Likert scale anchored $0=$ never, $1=$ almost never, $2=$ sometimes, 3 = frailty often, and $4=$ very often. The scores for items $4,5,7$, and 8 were reversed as $0=4,1=3,2=2,3=1$, and $4=0$. 
Subsequently, the scores were added together to obtain a total score between 0 and 40 . The higher scores indicated higher perceived stress. Scores ranging from $0-13$ were considered as low stress, $14-26$ as moderate stress, and $27-40$ as high perceived stress [9]. Cronbach's alpha of 0.780 was obtained for the PSS items in this study. The 10-item PSS measured global perceived stress expressed by individuals for the past 30 days.

A minor modification was made in the first and third questions only to adapt to the situation of the outbreak. The revised first question was: "In the last month, how often have you been upset because of the coronavirus outbreak that happened unexpectedly?" The third revised question was: "In the last month, how often have you felt nervous and stressed due to coronavirus outbreak?"

\section{STATISTICAL ANALYSIS}

The descriptive characteristics of the participants were presented in mean and standard deviation or number and percentage. The level of perceived stress in doctors was determined in mean and standard deviation. The prevalence of different levels of stress was determined in number and percentage. The comparison of perceived stress in doctors with different specialties and genders was examined in ANOVA-one way and independent $t$-test, respectively. The difference in the prevalence of perceived stress in different specialties and genders was examined in the Pearson's Chi-squared test.
The correlation of the perceived stress with the duration of dealing with suspected/confirmed cases of COVID-19 was examined using Pearson correlation. The significant difference was determined in a P-value of less than 0.05 . The statistical calculations were performed by statistical package for social sciences version 25 (IBM SPSS Statistics for Windows, Version 25.0. Armonk, NY: IBM Corp).

\section{ETHICAL CONSIDERATIONS}

A written consent form was taken from all doctors before filling the pre-designed questionnaire. The confidentiality of the personal information of the doctors was protected throughout the study steps.

\section{RESULTS}

The mean age of the physicians was 36.84 (SD: 7.81), and ranged between 23 and 69 years. Doctors' experience in medicine ranged between 0 and 42 years, with a mean experience of 11.83 years. The doctors were males $(74.6 \%)$ and females $(25.4 \%)$. The duration of dealing with suspected/ confirmed cases of COVID-19 ranged between 0 and 16 days, with a mean of 1.2 days (SD: 0.90). The mean level of stress was 18.81 of 40 and ranged from 1 to 36 . The study showed that most of the physicians had a moderate level of stress $(69.4 \%)$, followed by a low (21.1\%) and a high level of stress $(9.6 \%)$, see Table 1.

Table 1

General characteristics and prevalence of stress in physicians

\begin{tabular}{|c|c|c|}
\hline \multirow{2}{*}{ Characteristics $(n=209)$} & \multicolumn{2}{|c|}{ Statistics } \\
\hline & Mean & Std. Deviation \\
\hline Age (Range: $23-69$ years) & 36.84 & 7.81 \\
\hline \multirow[t]{2}{*}{ Experience in medicine ( $0-42$ years $)$} & 11.83 & 7.14 \\
\hline & Number & Percentage \\
\hline \multicolumn{3}{|l|}{ Gender } \\
\hline Male & 156 & 74.6 \\
\hline Female & 53 & 25.4 \\
\hline Days dealt with COVID-19 patients (Range: 0-16) & 1.2 & 0.90 \\
\hline Total stress level (range: 1-36) & 18.81 & 6.53 \\
\hline \multicolumn{3}{|l|}{ Stress } \\
\hline Low & 44 & 21.1 \\
\hline Moderate & 145 & 69.4 \\
\hline High & 20 & 9.6 \\
\hline
\end{tabular}

Table 2 presents the mean score and the prevalence of the perceived stress in medical specialists. With respect to the mean score of the perceived stress, the comparison of total mean stress score among physicians from different specialties showed that general physicians and medical lab specialties had a higher score of perceived stress compared to other specialties; 21.56 and 19.88 with a moderate level of stress ( $70.0 \%$ and $87.5 \%$ ), respectively.

Concerning the prevalence of perceived stress, the study showed that most of the medical specialties had a moderate level of perceived stress. The general 
physicians and community and family medicine doctors had a high level of stress; $20.0 \%$ and $25.0 \%$, respectively. Half of the pediatricians had a low level of stress $(50.0 \%)$ with no high-stress levels and had the lowest score of perceived stress (Mean: 14.50) (Table 2; Fig 1a).

Table 2

Comparison of total stress level among different specialty physicians

\begin{tabular}{|c|c|c|c|c|c|c|c|}
\hline \multirow{2}{*}{ Characteristics $(n=209)$} & \multirow{2}{*}{$\mathbf{n}$} & \multicolumn{2}{|c|}{ Stress score } & \multicolumn{3}{|c|}{ Stress Levels n(\%) } & \multirow{2}{*}{ P-Value } \\
\hline & & Mean & SD & Low & Moderate & High & \\
\hline Medical specialties & & & & & & & $0.018^{*}$ \\
\hline Anesthesia and intensive care & 15 & 16.53 & 4.84 & $4(26.7)$ & $11(73.3)$ & $0(0.0)$ & \\
\hline Medical lab specialties & 8 & 19.88 & 5.51 & $1(12.5)$ & $7(87.5)$ & $0(0.0)$ & \\
\hline Internal medicine & 39 & 17.62 & 6.05 & $8(20.5)$ & 31 (79.5) & $0(0.0)$ & \\
\hline Community and family medicine & 4 & 18.50 & 7.94 & $1(25.0)$ & $2(50.0)$ & $1(\mathbf{2 5 . 0})$ & \\
\hline Surgery specialties & 69 & 18.90 & 6.30 & $15(21.7)$ & $45(65.2)$ & $9(13.0)$ & \\
\hline General physicians & 50 & 21.56 & 6.81 & $5(10.0)$ & $35(70.0)$ & $10(\mathbf{2 0 . 0})$ & \\
\hline Obstetrics and Gynecology & 9 & 17.56 & 7.49 & $2(22.2)$ & 7 (77.8) & $0(0.0)$ & \\
\hline Pediatrics & 10 & 14.50 & 6.90 & $5(50.0)$ & $5(50.0)$ & $0(0.0)$ & \\
\hline Radiology & 5 & 15.60 & 5.81 & $3(60.0)$ & $2(40.0)$ & $0(0.0)$ & \\
\hline Gender & & & & & & & $0.001^{* *}$ \\
\hline Male & 156 & 18.2 & 6.3 & $36(23.1)$ & $107(68.6)$ & $13(8.3)$ & \\
\hline Female & 51 & 21.4 & 6.0 & $8(15.1)$ & $38(71.7)$ & $7(13.2)$ & \\
\hline Dealing with COVID-19 patients & & & & & & & $0.786^{* *}$ \\
\hline Yes & 180 & 19.02 & 6.4 & $38(21.1)$ & $124(68.9)$ & $18(10.0)$ & \\
\hline No & 29 & 18.87 & 5.7 & $6(20.7)$ & $21(72.4)$ & $2(6.9)$ & \\
\hline
\end{tabular}

${ }^{*}$ One-way ANOVA and ${ }^{* *}$ Independent t-test was performed for statistical analyses.

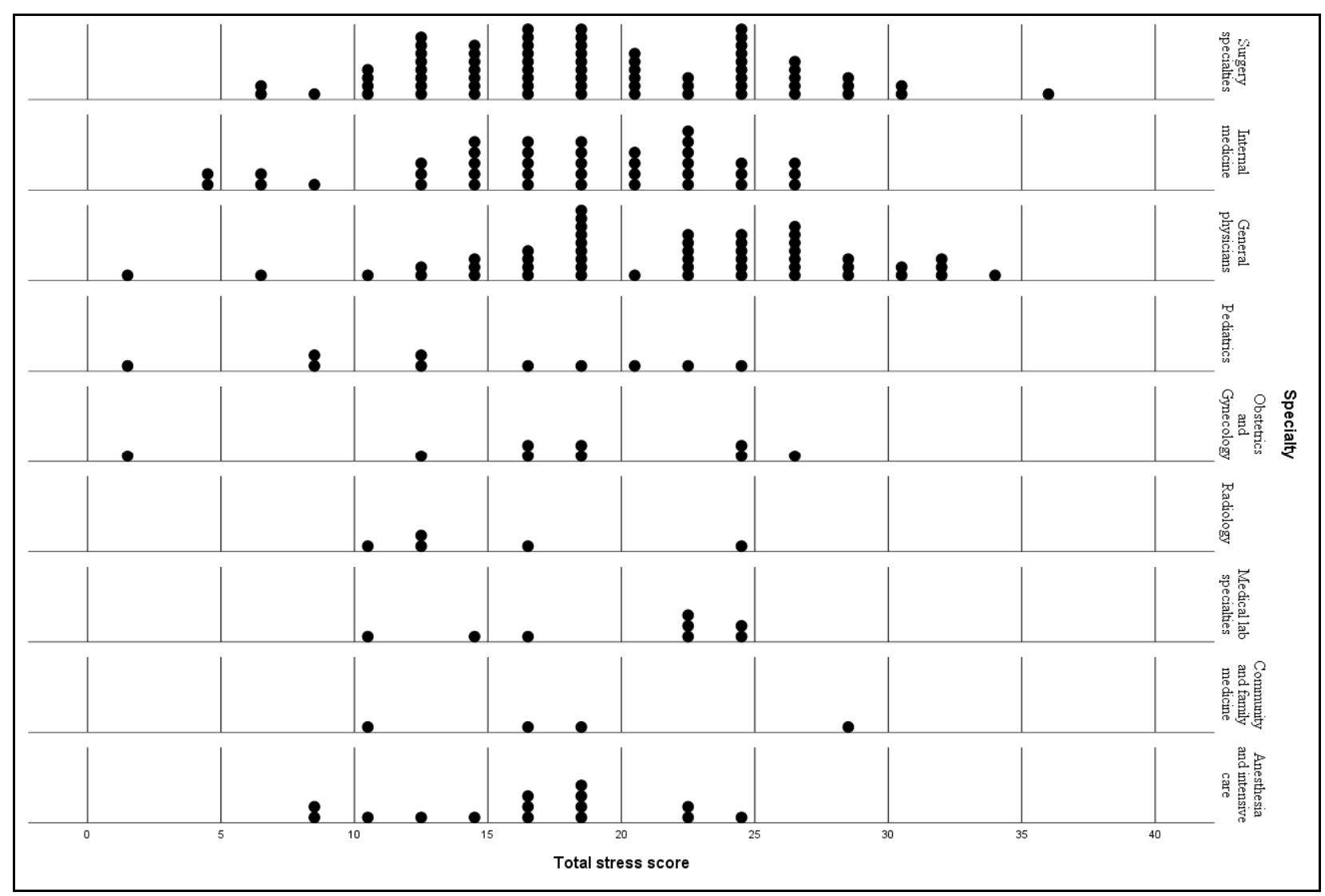

Figure 1a. Distribution of total stress score in physicians with different specialties.

The female doctors had a significantly higher score of perceived stress (Mean: 21.4; SD: 6.01) compared to male doctors (Mean: 18.2;
SD: 6.3; $\mathrm{P}=0.001)$. The female doctors had more percentages with moderate $(71.7 \%)$ and high-stress levels $(13.2 \%)$ compared to the males $(68.6 \%$ and 
$8.3 \%$ ), respectively. Whether or not doctors dealt with suspected/confirmed cases of COVID-19 had no significant difference over the perceived stress score; 19.02 vs. $18.87 ; \mathrm{P}=0.786$ ). Whether or not doctors dealt with suspected or confirmed cases of COVID-19, a majority of them had a moderate level of perceived stress, $68.9 \%$ and $72.4 \%$ " (Table 2; Fig 1b).

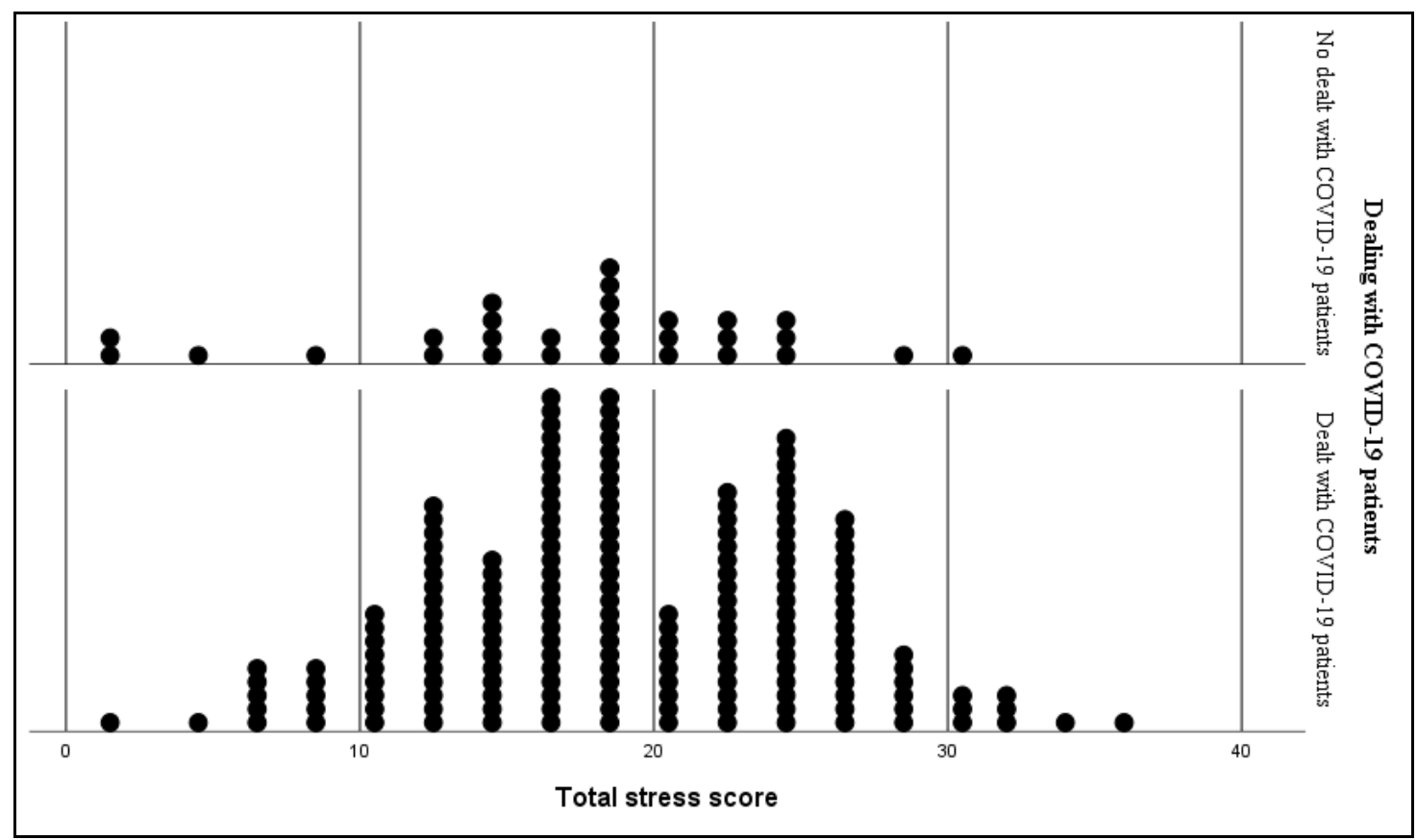

Figure 1b. Distribution of total stress score in physicians who dealt and not dealt with COVID-19 patients.

The study showed that the mean score was raised with increasing the number of the days that doctors dealt with suspected/confirmed cases of COVID-19; $r=0.202 ; \mathrm{P}=0.004$. However, the stress level was decreased with increasing age $(\mathrm{r}=-0.141$; $\mathrm{P}=0.045)$, and experience $(\mathrm{r}=-0.139, \mathrm{P}=0.048)$ (Table 3, and Fig 1c).

Table 3

Correlation of total stress score with the number of days that doctors dealt with suspected/confirmed cases of COVID-19

\begin{tabular}{lccc}
\hline \multicolumn{1}{c}{ Total stress score } & \multicolumn{3}{c}{ Controlling factors } \\
\cline { 2 - 4 } & Days of dealing & Age & Experience \\
\hline Correlation Coefficient & $0.202^{* * *}$ & -0.141 & -0.139 \\
Sig. (2-tailed) & 0.004 & 0.045 & 0.048 \\
\hline$* *$ Cor
\end{tabular}

${ }^{* *}$ Correlation is significant at the 0.01 level (2-tailed).

Pearson correlation was performed for statistical analysis. The correlation was adjusted for age, gender, specialty, and experience in medicine as required.

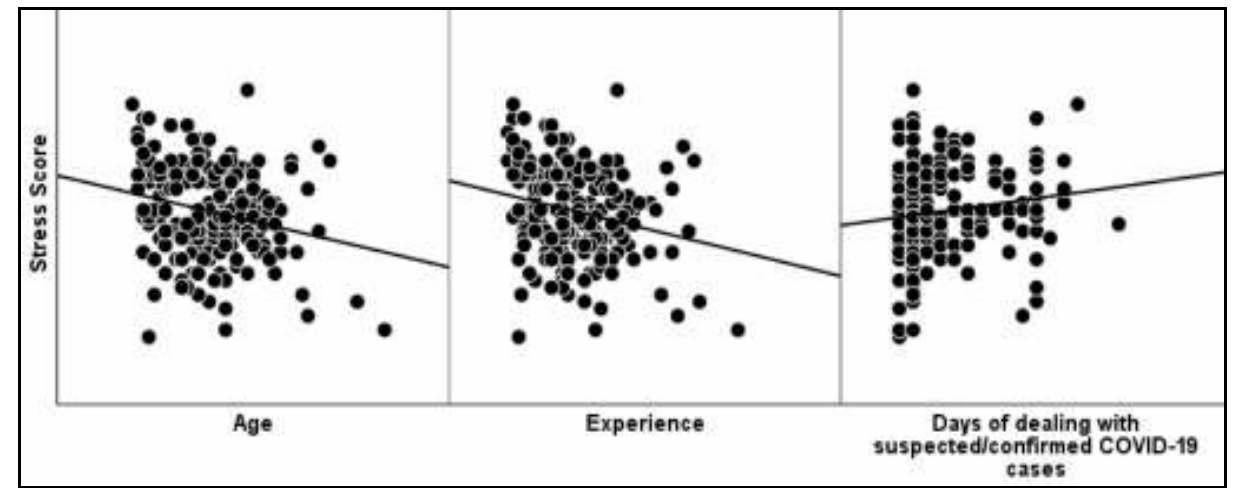

Figure 1c. Correlation of stress score with age, experience, and days of dealing in physicians. 


\section{DISCUSSIONS}

The present study showed that all the medical doctors who participated in this study had perceived stress, but with different severity. We did not find a doctor without stress. The pediatricians (including psychiatrists) had the lowest score of perceived stress, none of them with a high level of perceived stress. This study showed that no medical doctor is safe from perceiving stress during the outbreak in this region.

Cabello, Echavez et al. [6] reviewed the observational and experimental studies and examined the mental health impact of epidemic outbreaks on healthcare workers (HCWs). The study extracted study characteristics, symptoms, prevalence of mental health problems, risk factors, mental health interventions, and impacts. They reported that the pooled prevalence of anxiety was $45 \%$ (95\% CI $21-69)$, followed by depression (38\%, 95\% CI 15 to $60 \%)$, acute stress disorder $(31 \%, 95 \%$ CI 0 to $82 \%)$, burnout (29\%, 95\% CI 25 to $32 \%)$, and post-traumatic stress disorder (PTSD: $19 \%, 95 \%$ CI 11 to $26 \%$ ). The factors related to developing mental health issues were sociodemographic (younger age and female gender), social (lack of social support, social rejection, isolation, stigmatization), occupational (working in the frontline during an outbreak), and specific occupational factors like roles in medical settings. Maunder, Lancee et al. [10] reported that nurses and healthcare workers who have close contact with patients with severe acute respiratory syndrome have a higher level of psychological stress. The psychological stress was mediated by health fear, social isolation, and job stress.

We did not find a substantial difference in the perceived stress score between doctors who dealt or not with suspected/confirmed cases of COVID-19. This means that all doctors are at risk of perceiving stress during outbreaks. The challenges and the stress that doctors experience may trigger common mental disorders, such as anxiety, depressive disorders, and PTSD [11]. These mental disorders could result in hazards that raise the outcomes of the current COVID-19 outbreak [12]. Findings of a meta-analysis indicate that healthcare workers perceive personal and familial health risks and stigmatization from their exposure to emerging acute respiratory infectious diseases. They hypothesized that the perceptions of healthcare workers could impact their behaviors toward patients with respiratory infections [13].

Wong, Yau et al. [14] invited all doctors, nurses and healthcare assistants (HCA) working in the emergency departments (ED) of public hospitals. They examined the degree and the sources of mental distress and the coping strategies in HCWs who were working in emergency departments in Hong Kong during the SARS (severe acute respiratory syndrome) outbreak. The mean overall distress score was 6.19 out of a 10-point scale in HCWs, including 5.91, 6.52, and 5.44 in doctors, nurses, and HCA (healthcare assistants) respectively. The overall distress level was significantly higher in doctors and nurses compared to HCAs. We did not examine the level of perceived stress scores in nurses in this investigation. However, we anticipate that nurses have a higher level of perceived stress, similar to doctors, due to close contact with suspected/ confirmed cases of COVID-19. The general physicians and medical lab specialties had a higher mean score of perceived stress in this study.

The sources of distress were vulnerability/ loss of control, the health of self, the spread of the virus, the health of family and others, changes in work, and being isolated [14]. The study showed that nurses have a higher score of distress for all six sources. The HCAs had a significantly higher level of worrying about the family and others' health compared to physicians. They reported that physicians were more likely to use planning, and nurses to use behavioral disengagement, whereas HCAs were more likely to use self-distractions.

We found that general physicians and medical lab specialties have a higher mean score of perceived stress compared to other medical specialties. Community and family medicine doctors have the highest level of stress (25\%). This finding may back to the higher percentages of the female doctors in both specialties ( $3.8 \%$ vs. $1.3 \%)$, as females have a higher level of perceived stress compared to males. We feel that the general physicians and medical lab specialties have a higher perception of risk infection because they are in the frontline of the current outbreak in this region [15]. These physicians have to take care of the patients and they stay at the hospital for a longer time than other doctors do. Some specialties do not have daily commitments at hospitals. For example, surgeons do not have too much contact with the COVID-19 patients, but their mean score of perceived stress is close to the one among internal medicine specialists. It seems that there is a risk of infection everywhere during the outbreak. Possibly every doctor feels that he/she is at risk of infection. The general physicians and medical lab specialties have higher mean scores of perceived stress due to close contact with infected patients and body fluids (respiratory droplets). For 
instance, the attach rate on HCWs during nosocomial influenza outbreaks was anticipated to be as high as $60 \%$ [16]. Besides, the HCWs are at further risk of social isolation and stigmatization due to disease transmission. The HCWs perceive that they spread infectious diseases to friends and family [17].

The following factors have been reported to contribute to distress in HCWs during SARS. The factors are significant mortality, rapidly changing medical information and procedures, and uncertain pathogen, extraordinary infection control precautions, media scrutiny, stigmatization, reduced contact and interaction between colleagues, and frequent transmission of the infection to HCWs [17-21].

The difference in the intensity of distress among HCWs could be fully mediated by attitudinal responses to the outbreak and its circumstances [17]. It seems that female doctors have a higher fear of coronavirus infection in this region. Health fear is easily found out as a direct outcome of the circumstances for a doctor who is caring for patients with COVID-19, since the HCWs are at a high risk of infection and its substantial mortality [17].

The pediatrics (including psychiatrists) have the lowest mean score of perceived stress compared to other specialties. We back to this fact that they know how to deal with the current crisis. The psychosocial and mental health consequences of the pandemic are necessary to be addressed by psychiatrists and mental health professionals later after the outbreak. It must be considered that this study was conducted during the COVID-19 outbreak between 9th and 14th April 2020. The level of stress could be different during normal periods. By 16 April 2020, there were 15 confirmed cases of COVID-19 in Duhok governorate.

The mental health issues are required to be appropriately addressed since they have a long-lasting effect on HCWs [22]. In addition, they could hinder the urgent response to the current pandemic by escalating attention and decision-making [6]. Urgent convenient strategies are required to strengthen the HCWs against mental health problems [12]. Managing mental health and psychosocial wellbeing during this pandemic is as important as managing physical health. Feeling under pressure is a likely experience for everyone.

World Health Organization [23] advises some coping strategies like rest and respite during or between shift working, eating adequate and healthy food, involving in physical activity, and stay in contact with family and friends. The COVID-19 outbreak is considered to be a unique and unprecedented scenario for several healthcare workers, especially if they have not been involved in similar responses. The consequence of the pandemic on psychiatric problems must not be considered less important than on the physical ones.

The efforts to improve the effective interpersonal communication could help reducing the negative effects of social isolation [24]. Providing accurate information to the media in order to reduce stigmatizing reports, could be used by the medical settings, including careful evaluation, site by site, of the necessity of specific contact restrictions for infection control [21].

\section{LIMITATIONS OF THE STUDY}

Only two psychiatrists participated in this study, and they were child psychiatrists. This region has only five psychiatrists. Some other factors could have a role in establishing the perceived stress in medical doctors. However, the overall stress during the outbreak was more important for us in this study. The online assessment technique may not obtain the same results as face to face data collection, but we had no other option during the complete lockdown in this region. In addition, participants may have a certain degree of social assertiveness in their responses, which may bias the analysis.

\section{CONCLUSIONS}

The present study showed that medical doctors are at a moderate level of perceived stress during the COVID-19 outbreak in Iraqi Kurdistan, especially general physicians and medical lab specialties.

Introducere. Personalul sanitar se află la risc înalt să dezvolte probleme asociate stresului în timpul pandemiilor. Studiul îşi propune să evalueze stresul perceput de către personalul medical superior in timpul pandemiei COVID-19.

Materiale şi metode. Medicii care au lucrat în Irak (Kurdistan) în timpul pandemiei coronavirus au fost recrutaţi în acest studiu transversal. Doctorii proveneau din spitale de pediatrie, unitate primiri urgenţe, spitale suport COVID şi spital de ginecologie. Le-a 
fost administrat chestionarul PSS (Perceived Stress Scale-10 (PSS)) ce a măsurat stresul perceput de către cadrele medicale. Chestionarul a fost completat online.

Rezultate. Durata medie a contactului cu pacienţi COVID-19 pozitivi a fost de 1,2 zile (0-16 zile). Scorul mediu de stres a fost 18,81 din 40. Cei mai multi medici au avut un nivel de stres mediu $(69,4 \%)$ urmat de nivel de stres scăzut $(21,1 \%)$ şi nivel crescut $(9,6 \%)$. Medicii generalişti şi personalul de laborator au avut scoruri mai mari $(21,56$ şi 19,88). $\mathrm{Nu}$ a contat dacă medicii au avut contact direct cu pacienţi COVID-19 pozitivi scor mediu 19.02 versus $18,87, p=0,786$ ). Scorul mediu de stres a crescut odată cu durata creşterii contactului cu pacienţii COVID-19 pozitivi ( $r=0,202, p=0,004)$ şi a scăzut odată cu creşterea în vârstă $(r=-0,141, p=0,045)$ şi experienţa clinică $(r=-0,139$, $p=0,048$ ).

Concluzii. Studiul a arătat că medicii din Irak (Kurdistan) au avut un nivel moderat al stresului în timpul pandemiei COVID-19.

Correspondence to: DELDAR MORAD ABDULAH, Community Health Unit, College of Nursing, University of Duhok-Iraqi Kurdistan;

E-mail: deldarmorad@gmail.com,

Phone: +9647507443319;

Acknowledgments: The authors of the study would like to present their gratitude to the physicians who participated in this study.

Funding: The study was not funded by any organization.

Conflict of interest disclosure: The authors do not declare any conflict of interest.

\section{REFERENCES}

1. WANG, C, PW HORBY, FG HAYDEN, GF GAO, A novel coronavirus outbreak of global health concern. The Lancet, 2020. 395(10223):470-473.

2. FIORILLO, A, P GORWOOD, The consequences of the COVID-19 pandemic on mental health and implications for clinical practice. European Psychiatry, 2020:1-4.

3. KANG, L, Y LI, S HU, M CHEN, C YANG, BX YANG, et al., The mental health of medical workers in Wuhan, China dealing with the 2019 novel coronavirus. The Lancet Psychiatry, 2020. 7(3):e14.

4. BROOKS, SK, RK WEBSTER, LE SMITH, L WOODLAND, S WESSELY, N GREENBERG, et al., The psychological impact of quarantine and how to reduce it: rapid review of the evidence. The Lancet, 2020.

5. SHIGEMURA, J, RJ URSANO, JC MORGANSTEIN, M KUROSAWA, DM BENEDEK, Public responses to the novel 2019 coronavirus (2019-nCoV) in Japan: Mental health consequences and target populations. Psychiatry and clinical neurosciences, 2020.

6. CABELLO, IR, JFM ECHAVEZ, MJ SERRANO-RIPOLL, D FRAILE-NAVARRO, MAF DE ROQUE, GP MORENO, et al., Impact of viral epidemic outbreaks on mental health of healthcare workers: a rapid systematic review. medRxiv, 2020.

7. CHEN, R, K-R CHOU, Y-J HUANG, T-S WANG, S-Y LIU, L-Y HO, Effects of a SARS prevention programme in Taiwan on nursing staff's anxiety, depression and sleep quality: A longitudinal survey. International journal of nursing studies, 2006. 43(2):215-225.

8. WORLD HEALTH ORGANIZATION. Coronavirus disease 2019 (COVID-19). Situation Report - 70. 2020; Available from: https://www.who.int/docs/defaultsource/coronaviruse/situation-reports/20200330-sitrep-70-covid-19.pdf?sfvrsn=7e0fe3f8_2.

9. COHEN, S, T KAMARCK, R MERMELSTEIN, A global measure of perceived stress. Journal of health and social behavior, 1983:385-396.

10. MAUNDER, RG, WJ LANCEE, S ROURKE, JJ HUNTER, D GOLDBLOOM, K BALDERSON, et al., Factors associated with the psychological impact of severe acute respiratory syndrome on nurses and other hospital workers in Toronto. Psychosomatic Medicine, 2004. 66(6):938-942.

11. SHULTZ, JM, F BAINGANA, Y NERIA, The 2014 Ebola outbreak and mental health: current status and recommended response. Jama, 2015. 313(6):567-568.

12. BAO, Y, Y SUN, S MENG, J SHI, L LU, 2019-nCoV epidemic: address mental health care to empower society. The Lancet, 2020. 395(10224):e37-e38.

13. KOH, Y, DG HEGNEY, V DRURY, Comprehensive systematic review of healthcare workers' perceptions of risk and use of coping strategies towards emerging respiratory infectious diseases. International Journal of Evidence-Based Healthcare, 2011. 9(4):403-419.

14. WONG, TW, JK YAU, CL CHAN, RS KWONG, SM HO, CC LAU, et al., The psychological impact of severe acute respiratory syndrome outbreak on healthcare workers in emergency departments and how they cope. European Journal of Emergency Medicine, 2005. 12(1):13-18. 
15. ABDULAH, DM, RS PIRO, Role of media in perceived-vulnerability of the public towards coronavirus epidemic (COVID-19) in Iraqi Kurdistan. 2020, University of Duhok: Unpublished Work.

16. LOW, J, A WILDER-SMITH, Infectious respiratory illnesses and their impact on healthcare workers: a review. Ann Acad Med Singapore, 2005. 34(1):105-110.

17. MAUNDER, R, J HUNTER, L VINCENT, J BENNETT, N PELADEAU, M LESZCZ, et al., The immediate psychological and occupational impact of the 2003 SARS outbreak in a teaching hospital. Cmaj, 2003. 168(10):1245-1251.

18. NICKELL, LA, EJ CRIGHTON, CS TRACY, H AL-ENAZY, Y BOLAJI, S HANJRAH, et al., Psychosocial effects of SARS on hospital staff: survey of a large tertiary care institution. Cmaj, 2004. 170(5):793-798.

19. AVENDANO, M, P DERKACH, S SWAN, Clinical course and management of SARS in health care workers in Toronto: a case series. Cmaj, 2003. 168(13):1649-1660.

20. LANCEE, W, R MAUNDER, S ROURKE, J HUNTER, D GOLDBLOOM, K BALDERSON, et al., The acute traumatic impact of the SARS outbreak on hospital healthcare workers in Toronto. Psychosom Med, 2004. 66(1):A21.

21. MAUNDER, R, The experience of the 2003 SARS outbreak as a traumatic stress among frontline healthcare workers in Toronto: lessons learned. Philosophical Transactions of the Royal Society of London. Series B: Biological Sciences, 2004. 359(1447):1117-1125.

22. MAUNDER, RG, WJ LANCEE, KE BALDERSON, JP BENNETT, B BORGUNDVAAG, S EVANS, et al., Long-term psychological and occupational effects of providing hospital healthcare during SARS outbreak. Emerging infectious diseases, 2006. 12(12): 1924.

23. WORLD HEALTH ORGANIZATION. Mental health and psychosocial considerations during the COVID-19 outbreak. 2020; Available from: https:/www.google.com/url?client=internal-element-cse\&cx=partner-pub-3317167162609756:3134777453\&q=https:// www.who.int/docs/default-source/coronaviruse/mental-health-considerations.pdf\&sa=U\&ved=2ahUKEwixpo76-eroAhXGjqQK HV3fBA0QFjAAegQIABAC\&usg=AOvVaw2wV_JlcTeVo0ZI-y2EhrMG.

24. MCBRIDE, F, Communicating during a crisis - the SARS story at Mount Sinai Hospital. Hospital quarterly, 2003. 6(4):51-2, 3.

Received $14^{\text {th }}$ May 2020 